transcatheter aortic valve implantation. Interact Cardiovasc Thorac Surg. 2012; $14: 485-7$

3. Unbehaun A, Pasic M, Dreysse S, Buz S, Kukucka M, Hetzer R, Drews T. Transcatheter aortic valve implantation and hybrid coronary artery revascularizationtime to combine them. Innovations. 2011;6:395-8.

4. Walther T, Dewey T, Borger MA, Kempfert J, Linke A, Becht R, et al. Transapical aortic valve implantation: step by step. Ann Thorac Surg. 2009;87:276-83.
5. Pasic M, Dreysse S, Drews T, Buz S, Unbehaun A, Kukucka M, et al. Improved technique of transapical aortic valve implantation: "the Berlin addition" Ann Thorac Surg. 2010;89:2058-60.

6. Olsen LK, Arendrup H, Engstrom T, Sondergard L. When operable patients become inoperable: conversion of a surgical aortic valve replacement into transcatheter aortic valve implantation. Interact Cardiovasc Thorac Surg. 2009;9: $837-9$.

\title{
Warm beating heart with deep hypothermic circulatory arrest: A technique for an unclampable aorta with aortic valve regurgitation
}

\author{
Zain Khalpey, MD, PhD, MRCS, ${ }^{\text {a,b }}$ Rene J. Dekkers, CCP, ${ }^{\text {a,b }}$ Foeke J. H. Nauta, MD, ${ }^{\text {a,b }}$ and \\ Prem Shekar, MD, ${ }^{\mathrm{a}, \mathrm{b}}$ Boston, Mass
}

The presence of severe aortic insufficiency (AI) in patients with severe atherosclerotic disease of the ascending aorta at aortic valve replacement (AVR) poses considerable technical challenges, often associated with poor outcomes. $^{1,2}$ Furthermore, the risk of cerebral embolus precludes the use of an aortic crossclamp. ${ }^{1}$ The use of deep hypothermic circulatory arrest increases overall safety; however, it is associated with an increased risk of neurologic complications. ${ }^{3}$

We report a technique applied to 2 patients in which the heart was kept warm and beating in normal sinus rhythm while systemically cooling the body and organs. This strategy attempts to eliminate the ventricular fibrillation associated with hypothermia, avoiding left ventricular distension and endocardial ischemia, without clamping the aorta.

\section{METHODS}

After systemic heparinization, we cannulated the right axillary artery with an 8-mm Hemashield graft (Boston Scientific, Boston, Mass), connected to a $3 / 8 \times 3 / 8$ straight connector (Sorin Group, Arvada, Colo). Venous cannulation consisted of a $21 \mathrm{~F} 60-\mathrm{cm}$ Biomedicus (Medtronic, Minneapolis, Minn) femoral venous cannula placed percutanously into the right femoral vein and a single-stage malleable cannula placed into the superior vena cava (Medtronic). Cardiopulmonary bypass (CPB) was initiated. To prevent distension, both patients had a vent placed in the right superior pulmonary vein just after initiating $\mathrm{CPB}$ and before systemic cooling began. A retrograde coronary sinus cannula, either the Gundry

\footnotetext{
From the Deutsches Herzzentrum Berlin, Berlin, Germany.

Disclosures: Authors have nothing to disclose with regard to commercial support.

Z.K. and R.J.D. contributed equally to this work.

Received for publication Jan 19, 2012; revisions received March 9, 2012; accepted for publication March 19, 2012; available ahead of print April 16, 2012.

Address for reprints: Zain Khalpey, MD, PhD, MRCS, Department of Cardiac Surgery, Brigham and Women's Hospital, Harvard Medical School, 75 Francis St,

Boston, MA 02115 (E-mail: zkhalpey@partners.org).

J Thorac Cardiovasc Surg 2012;144:731-2

$0022-5223 / \$ 36.00$

Copyright (c) 2012 by The American Association for Thoracic Surgery

http://dx.doi.org/10.1016/j.jtcvs.2012.03.057
}

retrograde cannula (Medtronic) or the Edwards Life Science RC 2014 (Edwards Life Science, Irvine, Calif) was placed into the coronary sinus directly with echocardiographic assistance. The Sorin BCD Vanguard cardioplegia system (Sorin Group) was used to administer warm $\left(37^{\circ} \mathrm{C}\right)$ pump blood at $300 \mathrm{~mL} / \mathrm{min}$ into the coronary sinus. The retrograde circuit pressures reached $175 \mathrm{~mm} \mathrm{Hg}$, and coronary sinus pressures of 30 to $40 \mathrm{~mm}$ $\mathrm{Hg}$ were maintained while the patients were being cooled.

Systemic cooling with a $10^{\circ}$ to $12^{\circ} \mathrm{C}$ gradient to $22^{\circ}$ to $20^{\circ} \mathrm{C}$ was initiated with the Maquet Heater-Cooler Unit HCU 30 Dual Heater Cooler (MAQUET Cardiovascular, Wayne, NJ).

Below arterial $32^{\circ} \mathrm{C}$, an effort was made to safely decrease the CPB flow and thus the circuit line pressure, decreasing the incidence of competitive cold antegrade blood from the CPB in-flow cannula.

When the patient venous line and nasopharyngeal temperatures equalized at $22^{\circ} \mathrm{C}$ to $20^{\circ} \mathrm{C}, 30 \mathrm{mM}$ of systemic potassium was administered into the CPB pump to arrest the heart. The heart rate before potassium administration was bradycardic (22-30 beats/min), normal sinus rhythm Cold blood cardioplegia was administered to arrest the heart for the rest of the operation in an antegrade or retrograde route as per standard techniques.

\section{RESULTS}

Both patients underwent successful AVR and replacement of the ascending aorta. The duration of sinus bradycardia until cardiac arrest (ie, time of systemic cooling) was 60 and 65 minutes followed by potassium administration at $22.4^{\circ} \mathrm{C}$ at $20.0^{\circ} \mathrm{C}$, respectively. There was no operative mortality, and postoperatively, the patients showed no signs of neurologic sequelae.

\section{DISCUSSION}

This technique can be considered an alternative for patients in who aortic crossclamping is unsafe and might otherwise be inoperable.

Constant coronary perfusion, particularly in patients with hypertrophied ventricles, ${ }^{4}$ while maintaining sinus rhythm and cardiac contractions is crucial for optimal myocardial protection. $^{5}$ 
The authors would like to thank Wernard A. A. Borstlap, Amy Patel, and Dr Michael Davidson for their help.

\footnotetext{
References

1. Hiratzka LF, Bakris GL, Beckman JA, Bersin RM, Carr VF, Casey DE Jr, et al. 2010 ACCF/AHA/AATS/ACR/ASA/SCA/SCAI/SIR/STS/SVM guidelines for the diagnosis and management of patients with thoracic aortic disease. $J \mathrm{Am}$ Coll Cardiol. 2010;55:27-129.

2. Roberts WC, Vowels TJ, Ko JM, Filardo G, Hebeler RF Jr, Henry AC, et al.
} Comparison of the structure of the aortic valve and ascending aorta in adults having aortic valve replacement for aortic stenosis versus for pure aortic regurgitation and resection of the ascending aorta for aneurysm. Circulation. 2011; 123:896-903.

3. Aranki SF, Nathan M, Shekar P, Couper G, Rizzo R, Cohn LH. Hypothermic circulatory arrest enables aortic valve replacement in patients with unclampable aorta. Ann Thorac Surg. 2005;80:1679-86, 1677.

4. Wang J. Keeping the heart empty and beating improves preservation of hypertrophied hearts for valve surgery. J Thorac Cardiovasc Surg. 2006;132(6): 1314-20.

5. Macedo FI, Gologorsky E, Salerno TA. Beating-heart valve surgery: is the introduction of lung perfusion/ventilation the next step? Future Card. 2011;7: 61-7.

\title{
Percutaneous device closure of a pseudoaneurysm arising from the junction of the innominate artery and the aorta
}

\author{
Dawn C. Scantlebury, MBBS, ${ }^{a}$ Oluseun O. Alli, MBBS, ${ }^{a}$ Lyle D. Joyce, MD, ${ }^{\mathrm{b}}$ and Charanjit S. Rihal, MD, ${ }^{a}$ \\ Rochester, Minn
}

A percutaneous approach to management of thoracic aortic disease has emerged as an alternative to open surgical repair for carefully selected patients. Approaches that have been used include stent-grafting and coil embolization. We report a case of closure of a pseudoaneurysm of the junction of the innominate artery and the aorta with an Amplatzer Vascular Plug II (St Jude Medical, St Paul, Minn).

\section{CLINICAL SUMMARY}

A 46-year-old woman was seen for management of a right innominate artery pseudoaneurysm. Her surgical history included extensive anterior mediastinal and sternal resection in 2004 for recurrent Hodgkin lymphoma, and sternal reconstruction with polytetrafluoroethylene (Gore-Tex; W. L. Gore \& Associates, Inc, Flagstaff, Ariz) and transposition of the pectoralis majors. Seven years later after this operation, a painful pulsatile anterior chest wall mass developed. This was found to be a moderate-to-large innominate artery pseudoaneurysm that was closed percutaneously by deployment of a covered stent in the innominate artery. Some months later, her symptoms recurred. Repeated imaging

From the Department of Cardiac Surgery, ${ }^{\mathrm{a}}$ Brigham and Women's Hospital, Boston, Mass; and Department of Cardiac Surgery, ${ }^{\mathrm{b}}$ Harvard Medical School, Boston, Mass.

Disclosures: Authors have nothing to disclose with regard to commercial support.

Received for publication March 21, 2012; accepted for publication March 30, 2012; available ahead of print April 23, 2012.

Address for reprints: Dawn C. Scantlebury, MBBS, Mayo Clinic, Division of Cardiovascular Diseases, 200 First St SW, Rochester, MN 55905 (E-mail: Scantlebury. dawn@mayo.edu).

J Thorac Cardiovasc Surg 2012;144:732-4

0022-5223/\$36.00

Copyright (C) 2012 by The American Association for Thoracic Surgery

http://dx.doi.org/10.1016/j.jtcvs.2012.03.069 revealed recurrence and enlargement of the pseudoaneurysm, complete occlusion of the innominate artery near its origin, and retrograde filling of the right carotid and subclavian arteries from the left through the circle of Willis.

The patient was transferred to our institution for consideration for operative repair. In light of her surgical history, we believed that an attempt at open repair would be associated with significant risk. Review of the images revealed that the pseudoaneurysm arose from the junction of the aorta and the innominate artery (Figure 1, $A$ ), making it essentially an aortic pseudoaneurysm. Its neck was sufficiently narrow to attempt percutaneous repair with an Amplatzer device.

\section{Technique}

The procedure was performed in the cardiac catheterization laboratory with the patient under conscious sedation and local anesthesia. Access was obtained through a $6 \mathrm{~F}$ femoral arterial sheath. Aortic arch angiography, performed with a 6F-pigtail catheter, demonstrated complete occlusion of the innominate stent. A large pseudoaneurysm originated from the junction of the aorta-innominate junction (Figure 1, B).

Intravenous heparin was administered. The pigtail catheter was exchanged for an Amplatz left 1 catheter (Cook Medical Inc, Bloomington, Ind), which, over a stiff, angled guidewire, was carefully used to probe and cannulate the pseudoaneurysm mouth, followed thereafter by selective injection of the pseudoaneurysm (Figure 2, A). The pseudoaneurysm neck measured approximately $5 \mathrm{~mm}$ in diameter. With a 0.038-inch extra-stiff Amplatz guidewire for support, a 6F Shuttle sheath (Cook Medical) was advanced 